\title{
11
}

\section{Providing for rāhui in the law of Aotearoa New Zealand ${ }^{1}$}

\author{
Jacinta Ruru and Nicola Wheen
}

In this chapter we examine the place and nature of rāhui in the law of Aotearoa New Zealand. The expression rāhui is used in legislation in New Zealand to describe certain conservation areas (whenua rāhui, wahi rāhui) and associated conservation agreements (Nga Whenua Rāhui kawenata), and to denote particular means or measures that can be utilised for conservation or sustainability purposes. By so adopting the idea or expression of rāhui, New Zealand law can be seen to be drawing on one of the three original uses of rāhui: to replenish resources. In this sense, rāhui can be defined as a 'mark to warn people against trespassing; used in the case of tapu, or for temporary protection of fruit, birds, or fish etc' ${ }^{2}$ This chapter focuses on Nga Whenua Rāhui kawenata and rāhui around and under the Fisheries Act 1996 in particular, and discusses how the nature of and processes associated with rāhui have been defined by the legislation that applies in these two contexts.

1 This chapter is adapted from Wheen, Nicola and Ruru, Jacinta. Providing for 'Rahui' in the Law of Aotearoa New Zealand. Journal of the Polynesian Society, 20(2) 2011: 169-182.

2 Williams, H.W., 1971. Dictionary of the Maori Language. 7th edn. Wellington: GP Publications, p. 321. 
Legislative incorporations of rāhui deserve analysis: rāhui was and is a key concept in Maori culture and, as a means of regulating human activities to sustain resources, it was and is widely utilised and understood. The extent to which resource management law in Aotearoa New Zealand accurately and sympathetically recognises, supports and affirms rāhui is a yardstick for how well environmental governance here complies with the New Zealand Crown's Treaty of Waitangi guarantee of Maori rangatiratanga (self-determination) over natural resources.

Ultimately, the analysis herein reveals some important differences between rāhui as originally understood and rāhui as a legislative construct. These differences may be rationalised or understood in more than one way. The differences may indicate a lack of understanding of rāhui on the part of legislators, or an unwillingness (again on the part of legislators) to create a legal form of rāhui that accurately replicates the practice and origins of the concept. On the other hand, the differences between rāhui as originally understood and described, and rāhui as it appears in legislation in Aotearoa New Zealand, may be seen, as indeed Maxwell and Penetito argue, to show that 'the custom of rāhui has changed and that rāhui are instated, enforced and lifted differently in modern times as compared to the original methods'. ${ }^{3}$ In this case, the decisions that legislators have made about how to define rāhui and its associated processes and implications are part of the social fabric that, over the years, has remodelled and redefined what rāhui in Aotearoa New Zealand is and what it means.

\section{Tikanga Maori and rāhui}

The Maori phrase for law - tikanga Maori - involves an 'obligation to do things in the "right" way' or 'way(s) of doing and thinking held by Maori to be just and correct'. ${ }^{4}$ The tikanga of rāhui is an integral

3 Maxwell, K.H. \& Penetito, W., 2007. 'How the use of rāhui for protecting taonga has evolved over time'. MAI Review 2: 2, www.review.mai.ac.nz.

4 New Zealand Law Commission, 2001. Maori Custom and Values in New Zealand Law. Study Paper 9. Wellington: Law Commission, p. 16. 
component of the Maori world. The effect of the rāhui is to "prohibit a specific human activity from occurring or from continuing.'. According to Maxwell and Penetito:

The definition of rāhui has not changed through time. Early accounts describe rāhui as a prohibition or to prohibit ... Modern definitions of rāhuitai include: banned, out of bounds, forbidden, prohibited, under sanctuary, reserved or preserved ... [I]nstalling a rāhui ... will 'prohibit the use of one or more resources in a given area'. ${ }^{6}$

However, as Maxwell and Penetito also go on to say:

The literature suggests that the custom of rāhui has changed and that rāhui are instated, enforced and lifted differently in modern times as compared to the original methods ... The methods by which rāhui are instated have changed and it is likely that milder forms are introduced today. ${ }^{7}$

As Mead observes, the rāhui is a 'creative tool capable of being applied in a variety of situations for a wide variety of reasons' ${ }^{8}{ }^{8}$ Rāhui have been used, and are regularly still used, to separate people from land and water (and their products) that have been contaminated by the tapu of death. Rāhui of a form Mead calls 'conservation rāhui':

seem to have been associated ... with control of resources or the good of the whole community [and] also with the political use of resources. In the former, common-sense regulation of bird, fish and plant life seems to have been a consideration ... [It is also] evident that the conservation rāhui was sometimes used by the chiefs for political reasons which might have been related to the 'foreign policy' of the tribe or might have been for the personal aggrandisement of the rulers. ${ }^{9}$

Some more severe rāhui were originally instated by tohunga, calling on the 'dread powers of the gods to enforce them'.$^{10}$ Other 'milder' rāhui could be instated by a 'chief or tohunga [skilled spiritual person] ... simply stat[ing] that he is placing a rāhui over an area and it would

5 Mead, H.M., 2003. Tikanga Maori. Living by Maori Values. Wellington: Huia Publishers, p. 193.

6 Maxwell \& Penetito, 2007, p. 1.

7 Maxwell \& Penetito, 2007, p. 2, emphasis added.

8 Mead, 2003, p. 203.

9 Mead, 2003, p. 203.

10 Maxwell \& Penetito, 2007, p. 2. 
be so'. ${ }^{11}$ A pou rāhui, or post, was almost always 'put up' to indicate that a rāhui was in place. ${ }^{12}$ Prior to colonisation, the introduction of Christianity and the suppression of tohunga, transgression of rāhui was punishable by extreme measures including war, death and muru (ritual redistribution of wealth as compensation). As Mead states: 'Today, however, the rāhui is still honoured essentially because it is regarded as a sacred ritual of the traditional past [that is] still useful ... ' ${ }^{13}$

As earlier stated, in this chapter we examine the place and nature of rāhui in the law - particularly the legislation - of Aotearoa New Zealand. Before beginning, it is necessary to provide some background on the law of Aotearoa New Zealand and tikanga Maori, the Treaty of Waitangi, and the status and ownership of land and resource management and conservation in Aotearoa New Zealand.

\section{Necessary background}

\section{The Treaty of Waitangi, Tikanga Maori and the law}

In 1840, Captain William Hobson, representing the British Crown, and over 500 Maori chiefs signed te Tiriti o Waitangi (the Treaty of Waitangi). ${ }^{14}$ It is a short document, consisting of three articles. While the Maori version explicitly states that Maori ceded to the Crown governance only (article 1), and retained tino rangatiratanga (sovereignty, article II) over their taonga (treasures), the British Crown assumed sovereignty over the country in accordance with the English version of the treaty and Aotearoa New Zealand became subject to colonial rule. ${ }^{15}$ Henceforth, there were repeated and ongoing breaches of the Crown's guarantees in the treaty.

\footnotetext{
11 Maxwell \& Penetito, 2007, p. 2.

12 Mead, 2003, p. 197, who notes that 'putting up' a post might have meant hanging a garment on a post, or smearing a post with red orchre, instead of actually erecting a post.

13 Mead, 2003, p. 202.

14 To view a copy of the Treaty, see First Schedule of the Treaty of Waitangi Act 1975 or the NZ Government's official Treaty website: www.treatyofwaitangi.govt.nz.

15 Miller, R.J., \& Ruru, J., 2009. 'An indigenous lens into comparative law: the doctrine of discovery in the United States and New Zealand'. West Virginia Law Review 111: 849-918.
} 
As colonial rule was applied to Aotearoa New Zealand so were English legal rules and constitutional assumptions. Formal law - made by parliament and interpreted and applied by courts - became the dominant regime, displacing tikanga Maori. Land was subject to private ownership and transfer. Central and local government was installed to provide infrastructure and manage and control natural resources. Significantly, parliament became the supreme lawmaker and the Treaty of Waitangi and its guarantees were - and still are not part of domestic law unless included by parliament in legislation. Through until the 1980s, the colonial parliament and courts recognised few, limited instances of tikanga Maori. ${ }^{16}$ During the 1980s and 1990s, however, references to the 'principles' of the Treaty of Waitangi and to tikanga concepts, such as kaitiakitanga (guardianship) and wahi tapu (sacred place), were persistently included in significant environmental legislation, including the Environment Act 1986, Conservation Act 1987, and Resource Management Act 1991. These legislative references to the treaty principles and to tikanga concepts reflected a wider policy shift on the part of government and parliament towards reconciling with, rather than assimilating, Maori. ${ }^{17}$

The shift towards reconciliation and away from assimilation was perhaps most obviously manifest in the establishment of the Waitangi Tribunal in the Treaty of Waitangi Act 1975. This permanent commission of inquiry is empowered to receive, report on and recommend redress for Maori-alleged Crown breaches of the principles of the Treaty of Waitangi. ${ }^{18}$ Since it was established, the tribunal has reported on over 100 claims by Maori concerning matters ranging from the Crown's failure to protect mahinga kai (seafood gardens and other traditional sources of food) to the Crown's unlawful confiscation of land during the so-called land wars. Its recommendations have formed the basis of a number of settlements subsequently reached between the Crown and complainant Maori groups. More recently, the establishment within the Ministry of Justice of the Office of Treaty Settlements, with its mandate to resolve historical breaches of the Treaty of Waitangi,

16 Ruru, J., 2008. 'Finding solutions for the legislative gaps in determining rights to the family home on colonially defined indigenous lands'. U.B.C. Law Review 41(2): 315-48.

17 See Ruru, J., 2009. 'The Maori encounter with Aotearoa New Zealand's legal system'. In B. Richardson, S. Imai \& K. McNeil (eds), Indigenous Peoples and the Law: Comparative and Critical Perspectives. Oxford: Hart Publishing, pp. 111-33.

18 See, generally, Hayward, J. \& Wheen, N.R. (eds), 2004. The Waitangi Tribunal. Te Roopu Whakamana i te Tiriti o Waitangi. Wellington: Bridget Williams Books Ltd. 
has played a pivotal role in reconciling with Maori. To date, more than 50 groups have successfully negotiated, or are in advanced stages of negotiating, tribal redress from the Crown. ${ }^{19}$ More than 18 of these negotiated settlement agreements have been implemented in Acts of parliament. These Acts typically contain Crown apologies for wrongs done, various forms of financial or commercial redress, and redress recognising the claimant group's spiritual, cultural, historical or traditional associations with the natural environment. ${ }^{20}$

\section{Land ownership and resource management}

All land in Aotearoa New Zealand was once Maori customary land. Some of this land was unlawfully confiscated by the Crown, some land was legitimately sold or gifted to the Crown, but the majority of it became reclassified as Maori freehold land pursuant to the work of the then-named Native Land Court and was subsequently sold or confiscated. Today, about 6 per cent of the country is classified as Maori freehold land. A large chunk of the country is in Crown ownership, including 30 per cent of the landmass that is managed by the Department of Conservation. General, or private, land constitutes the other large component of land type.

The Department of Conservation was established in 1987 to manage natural resources held by it for conservation purposes (Conservation Act, s 6). The department, along with the New Zealand Conservation Authority and conservation boards, is responsible for devising and administering a policy and planning framework for conservation of lands and resources, and also for the day-to-day management and administration of those lands and resources. Much of the land administered by the department is Crown owned, but an increasing proportion is privately owned. Beyond the areas managed by the department, regional and local authorities and the Environment Court are responsible for land-use planning and for regulating access to and use of land, air and water (Resource Management Act 1991) and, importantly in the context of this chapter, the Ministry of Fisheries ultimately manages and controls customary, recreational and commercial fisheries (Fisheries Act 1996).

19 See Office of Treaty Settlements' website: www.ots.govt.nz.

20 For example, see: Ngai Tahu Claims Settlement Act 1998 and Te Roroa Claims Settlement Act 2008 . 


\section{Instances of rāhui in the law}

The term rāhui appears only a handful of times in the legislation of Aotearoa New Zealand. In all cases, it is used to refer to a means or device 'to restore the productivity of land'21 or to 'allow the mauri (life essence) of a resource or resources to replenish'.$^{22}$ In this section, we describe and comment on these references.

The first reference to rāhui appears in the Ngati Awa Claims Settlement Act 2005. This Act gives statutory effect to the settlement of Treaty of Waitangi claims between Ngati Awa iwi (tribe) and hapu (sub-tribe) and the New Zealand Crown. The Act refers to accounts of historic instances of the use of rāhui to support the association of Ngati Awa with two specific sites: Moutohora and Ohiwa Harbour. ${ }^{23}$ Those accounts are manifest and recorded in the schedules to the Act. This is a simple acknowledgement both of the importance of rāhui as a form of social and environmental control, and of the fact that the authority to utilise rāhui attaches to individuals within the group holding mana whenua (authority) over the area.

Second, legislation has used the term rāhui to describe or refer to certain kinds of conservation land reserves: Nga Whenua rāhui and whenua rāhui. The inclusion of rāhui in the names given to these reserves indicates that these are places where activities may be restricted for restorative or conservation purposes.

\section{Nga Whenua rāhui}

Nga Whenua rāhui are areas of Maori land, or Crown land held under lease by Maori, that are being managed by the Department of Conservation pursuant to Nga Whenua Rāhui kawenata (Conservation Act 1987, s 27A or the Reserves Act 1977, s 77A(4)) or conservation covenants (Conservation Act, s 29 or Reserves Act, s 77). The minister of conservation has a statutory discretion to enter into a covenant or

\footnotetext{
21 Mead, 2003, p. 197.

22 Maxwell \& Penetito, 2007, p. 6.

23 More precisely, the two 'statutory areas' in respect of which the assocation by Ngati Awa is affirmed are the 'statutory area' known as Moutohora (Whale Island) Management Reserve (Ngati Awa Claims Settlement Act 2005 (No. 28), Schedule 7), and the 'statutory area' of part of the Ohiwa Harbour (Schedule 8).
} 
Nga Whenua Rähui kawenata with the owner or occupier of the land. Conservation covenants can be made with any such owner or occupier, but Nga Whenua Rāhui kawenata are specifically crafted for Maori landowners or occupiers. Nga Whenua Rāhui kawenata may be agreed to in order to 'provide for the management of the land in a manner that will achieve' the purposes of 'preserv[ing] and protect[ing]' the 'spiritual and cultural values which Maori associate with the land' or, either, the 'natural and historic values of the land' or 'the natural environment, landscape amenity, wildlife or freshwater-life or marinelife habitat, or historical value of the land' (Reserves Act, s 77A(1) and Conservation Act, s 27A(1)).

Nga Whenua Rāhui kawenata are administered by the Nga Whenua Rāhui fund, a contestible ministerial fund that was established in 1991. According to the Department of Conservation website, the 'criteria and mechanisms of Nga Whenua Rāhui, are geared towards the owners retaining tino rangatiratanga (ownership and control)' ${ }^{24}$ Each area is managed according to the terms of the applicable kawenata or covenant, and also according to the terms of the relevant legislation. Thus, for example, the offences prescribed in the Reserves and Conservation Acts for all reserves and conservation areas expressly apply to land administered under Nga Whenua Rāhui kawenata (Reserves Act, s 77A(1)(c) and Conservation Act, s 27(1)(c)).

Nga Whenua Rāhui kawenata may be agreed to for a specified term, or may be in perpetuity, either subject or not to a condition:

that at agreed intervals of not less than 25 years the parties to the Nga Whenua Rāhui kawenata shall review the objectives, conditions, and continuance of the Nga Whenua Rāhui kawenata; and on such review the parties may mutually agree that the Nga Whenua Rāhui kawenata shall be terminated, or the owner or lessee may terminate the Nga Whenua Rähui kawenata on giving such notice (being not less than 6 months) as may be agreed. The Crown shall have regard to the manawhenua of the owner or lessee in any such review.

McPhail observes that the option of a review within 25 years provides an important acknowledgement of some of the problems for landowners with conservation grants that are in perpetuity:

24 Department of Conservation website: www.doc.govt.nz/nga-whenua-rahui-fund. 
- Never having again the right to fully utilise their privately owned land.

- Changes in value over a period of years could make the amount paid for the purchase of the public good benefit look very small and inequitable.

- Aversion to parting with control over usage of land.

- No ability to review the terms of the deal after a reasonable period. ${ }^{25}$

Unfortunately, the option for review may be a reason for the Minister of Conservation having preferred, in some significant cases over the years, the option of a conservation covenant. ${ }^{26}$

\section{Whenua rāhui}

Whenua rāhui are sites identified as part of the Crown's Treaty of Waitangi claim settlement with Te Arawa Iwi and Hapū. This settlement is one of the negotiated treaty settlements earlier described. Several of these settlements have included some kind of statutory device that is designed to recognise Maori values in Crown land managed by the Department of Conservation. For example, one of the first settlement statutes, the Ngai Tahu Claims Settlement Act 1998, introduced the topuni device, which is derived 'from the traditional ... custom ... of persons of rangatira (chiefly) status extending their mana and protection over a person or area by placing their cloak over them or it' ${ }^{27}$ The 1998 Act's Schedules include Ngāi Tahu statements of value for 13 topuni sites, including Aoraki/Mount Cook. In both Acts, the values in each statement are acknowledged by the Crown, are to be notified and given particular regard by conservation authorities in managing the sites, and can provide the basis for the Crown and Ngāi Tahu or Affiliate Te Arawa (as the case may be) to agree on principles directed at the Minister of Conservation avoiding harm to values in the topuni or whenua rāhui site(s). If principles are agreed, the director-general

25 McPhail, D., 2002. Constraints and Opportunities for South Island Landless Natives Act (SILNA) 1906 Indigenous Forest Utilisation. Paper no. 3 from the research programme UoCX0004 Sustainability on Maori-Owned Indigenous Forest, School of Forestry. Christchurch: University of Canterbury, p. 52.

26 The two clear examples being the conservation covenants over the Waitutu and Lords River blocks (see the Waitutu Block Settlement Act 1997, Tutae-Ka-Wetoweto Forest Act 2001, McPhail (2002) and Wheen (2008)).

27 Te Rūnanga o Ngāi Tahu, 'Mana Recognition': www.ngaitahu.iwi.nz/ngai-tahu/thesettlement/settlement-offer/cultural-redress/ownership-and-control/mana-recognition/. 
of conservation must take action in respect of them. Furthermore, the Governor-General is authorised to make regulations, and the Minister of Conservation may make by-laws, to regulate or prohibit public activities in or in respect of topuni or whenua rāhui and to prescribe offences and penalties for breaches of any such restrictions (Ngai Tahu Claims Settlement Act 1998, ss 239-244; Affiliate Te Arawa Iwi and Hapū Claims Settlement Act 2008 ss 51-62).

The Act records the Crown's apology and provides cultural and commercial redress to the Affiliate Te Arawa Iwi. In s 11 of the Act, the Affiliate Iwi is defined as comprising 11 collective groups who, by whakapapa (genology) and choice, have agreed to this settlement with the Crown. An important component of settlement is the cultural redress package, which encompasses the use of the term whenua rāhui.

The whenua rāhui sites are legally described in s 4 of the Act. The schedule also recites a formal statement of affiliate values in each whenua rāhui. These statements describe the affiliate's traditional, cultural, spiritual and historical association with the whenua rāhui (s 49). These 'affiliate values' are expressly acknowledged by the Crown (s 51). The Act then authorises the Te Pumautanga o Te Arawa trustees and the Crown to agree on 'protection principles ... directed at' the Minister of Conservation 'avoiding harm to the Affiliate values in respect of the whenua rāhui' or 'avoiding the diminishing of Affiliate values in respect of the whenua rāhui' (s 53). The affiliate values and protection principles must be given 'particular regard' by the Crown, the New Zealand Conservation Authority (NZCA) or conservation boards when they consider and approve conservation documents or proposed changes to the conservation status of whenua rāhui (ss 54 and 55). The trustees are entitled to make submissions to the NZCA on any draft conservation strategy in respect of a whenua rāhui (s 56).

The formal declaration of a site as whenua rāhui must be publicly notified via conservation documents and the New Zealand Gazette (ss 57 and 58). The declaration obliges the director-general of conservation to 'take action' to implement the protection principles (s 59, although note that the director-general 'retains complete discretion to determine the method and extent of the action to be taken'). The Act also authorises the director-general to initiate changes to conservation documents to include objectives relating to the protection principles, and the Governor-General to make regulations - or the Minister of Conservation 
to make by-laws - to implement those objectives, or to regulate or prohibit activities in respect of whenua rāhui (ss 60-62). Whenua rāhui status does not, however, affect the existing classification of the site as a national park, conservation area or reserve (s 63). Nor do the terms of the Act create, grant or provide evidence of any estate, interest or rights in respect of whenua rāhui (s 67).

It is too early to comment on the success of the use of whenua rāhui as compared to other common cultural redress devices used in the conservation estate. It will be interesting to see if other iwi seek to utilise this concept in regard to their specific forthcoming settlements.

As well as these instances where rāhui is used by legislation to denote the conservation, or restricted, status of Nga Whenua Rāhui and whenua rāhui areas, the term is also expressly used in legislation to refer to a form of fisheries control and to a device for restricting access to a wetland. But, before discussing these two references to răhui, it is important to note that there are other occasions where legislation refers to or implements devices that look like rāhui, even though it does not actually call them rāhui. Two particular examples of this are formally referred to as rāhui in the literature about the relevant legislation. These examples concern access to fisheries and titi (muttonbird or sooty shearwater, Puffinus griseus).

\section{Titī}

Traditionally, tìtī was both an essential food source and a tradable commodity for Ngai Tahu (the predominant iwi in the South Island). The Titi Islands constitute approximately 36 islands clustered together in three main groups to the east, south and west of Rakiura Stewart Island at the bottom of the South Island. The harvesting of titi chicks has been 'an integral part of the Ngai Tahi economy for centuries'. ${ }^{28}$ Traditional rights to harvest chicks on the islands are founded on genealogy. Over the centuries, the harvest has been controlled by traditional ecological knowledge including the application of rāhui. According to Williams, the islands were, and are still, not visited between the end of May and the following March. ${ }^{29}$ Significantly, this

\footnotetext{
28 Te Rūnanga o Ngāi Tahu 'Four Specific Sites': www.ngaitahu.iwi.nz/About-Ngai-Tahu/ Settlement/Settlement-Offer/Cultural-Redress/Four-Specific-Sites.php.

29 Williams, J., 2004. E Pakihi Hakinga a Kai: An Examination of Pre-contact Resource Management Practice in Southern Te Wai Pounamu. PhD thesis, University of Otago, p. 140.
} 
centuries old rāhui is now codified in the Titi (Muttonbird) Islands Regulations 1978. Eligible persons may only enter the islands during the birding season, which is defined as a period commencing on 1 April in any year and ending on 31 May in the same year. ${ }^{30}$ While the regulations do not themselves use the word rāhui, they do effectively implement the substance of this rāhui.

The regulations were made by the Crown but, since the Ngai Tahu Treaty of Waitangi claims settlement (see the Ngai Tahu Claims Settlement Act 1998), they are administered and the islands are managed by Rakiura Maori, and the islands are owned by Te Runanga o Ngai Tahu.

\section{Tutaepatu wetland/lagoon}

Tutaepatu Lagoon is a coastal wetland situated north of Kaiapoi in the South Island. In 1995 the Waitangi Tribunal made its report on certain ancillary claims by Ngai Tahu, one of which concerned the loss of the Tutaepatu Lagoon. ${ }^{31}$ This lagoon was and is of importance to Ngai Tahu as 'kainga nohoanga [permanent settlements], mahinga kai and urupa [cemetery]'. ${ }^{32}$ Following the tribunal's findings, parliament enacted the Ngai Tahu (Tutaepatu Lagoon Vesting) Act 1998. The Act vests ownership of the lagoon in Te Runanga o Ngai Tahu (see s 6). Te Runanga o Ngai Tahu must manage the lagoon in accordance with the objectives set out in Appendix 3 of the Act (see s 7). The five objectives include, for example, restoring and maintaining the lagoon for the benefit of present and future generations and actively encouraging scientific research and observation of the flora and fauna. Principle two is of particular interest to us. It reads: Appropriate public access to the Lagoon/wetlands will be allowed except for those times when, after notification in the local newspaper, a rāhui is applied'. This legislation thus envisages the use of rāhui and, although it does not confer or affirm the power to install the rāhui, it recognises the authority of Ngai Tahu to do so and thereby protect the resources of the lagoon.

\footnotetext{
30 See regs 2 and 3; Stevens, M.J., 2006. 'Kāi Tahu me to Hopu Tìtī ki Rakiura: an exception to the "colonial rule"?' Journal of Pacific History 41(3): 273-91.

31 See the Ngai Tahu Ancillary Claims Report, 1995.

32 Bennion, T., 1997. 'Ngāi Tahu (Tutaepatu Lagoon Vesting) Bill' Maori Law Review at www. maorilawreview.co.nz/1997/11/november-1997-contents/\#more-300.
} 


\section{Fisheries - mātaitai reserves and temporary closures}

Maxwell and Penetito argue that today, 'voluntary rāhui are primarily used to protect aquatic resources'. They cite examples of the use of voluntary (informal, non-legal) rāhui from the Mahia Peninsula and Kaikoura, noting that in remote places 'with a small population that respects either the tikanga of rāhui and/or the resource', voluntary rāhui may have strength but 'in areas of New Zealand that are readily accessible to larger populations, voluntary rāhui are becoming increasingly ignored' ${ }^{33}$ In such cases, formal temporary closures of the relevant fisheries by the minister or the chief executive of fisheries have sometimes followed. The Fisheries Act 1996 (ss 186A and 186B) allows for such temporary closures of fishing areas to fishing to provide for the use and management practices of tangata whenua in the exercise of their customary, non-commercial fishing rights. According to the Ministry of Fisheries website:

Temporary closures are designed to respond to localised depletion of fisheries resources. Note that in this context, Tangata Whenua means the hapu or iwi that hold manawhenua in the area. Anyone (not just Tangata Whenua) can request a s 186A (North Island/Chathams) and $186 \mathrm{~B}$ (South Island) temporary closure, but the legislation is designed for customary purposes so must meet that purpose and have the support of Tangata Whenua if they are not the applicants. ${ }^{34}$

Although the Fisheries Act does not refer to such closures as rāhui, the ministry's official website frequently does so. As discussed below, this may prove to be a more significant point than it at first appears.

The one occasion when fisheries legislation in Aotearoa New Zealand expressly employs the term rāhui is in the context of mātaitai reserves. A mätaitai reserve is defined as an identified traditional fishing ground established pursuant to the Fisheries (South Island Customary Fishing) Regulations 1999, the Fisheries (Kaimoana Customary Fishing) Regulations 1998 and the Fisheries Act 1996. Along with temporary closures and taiapure fisheries (a local management tool established in an area that has customarily been of special significance to an iwi or hapu as a source of food or for spiritual or cultural reasons - see

33 Maxwell \& Penetito, 2007, pp. 8, 9.

34 www.mfish.govt.nz. 
s. 174 of the Fisheries Act 1996), mätaitai reserves comprise one of the legislation's key measures for recognising and providing for Maori customary fishing rights and interests. According to customary fishing regulations, the minister may establish a mätaitai reserve in traditional fishing grounds in order to recognise and provide for customary management practices and food gathering (Fisheries (South Island Customary Fishing) Regulations 1999, reg 20, and Fisheries (Kaimoana Customary Fishing) Regulations 1998, reg 23). The tangata whenua can nominate Tangata Tiaki or Kaitaki (nominations must be confirmed by the minister following a process of public consultation) who are authorised to make by-laws restricting or prohibiting commercial fishing in reserves if this is considered 'necessary for the sustainable management' of the fish, aquatic life, or seaweed therein (Fisheries (South Island Customary Fishing) Regulations 1999, reg 25 and Fisheries (Kaimoana Customary Fishing) Regulations 1998, reg 28). These by-laws are not called rāhui, although Tangata Tiaki/ Kaitiaki are further required to report annually to the tangata whenua on matters relating to the management of the reserve, including any rāhui in force in the relevant year (Fisheries (South Island Customary Fishing) Regulations 1999, reg 37 and Fisheries (Kaimoana Customary Fishing) Regulations 1998, reg 40). It is not clear if this reference is intended to link back to the power to make by-laws to restrict or ban commercial fishing in the reserve, but this may be implied. Thus the legislature may be seen to have envisaged the deployment of rāhui via by-laws within mātaitai reserves.

\section{Comment}

In summary, the legislation of Aotearoa New Zealand refers to or adopts the concept of rāhui somewhat inconsistently. In legislation, the term rāhui is always used to invoke the form of rāhui that involves allowing the mauri of a resource to replenish, or promoting resource sustainability or conservation. However, the legislation only sometimes recognises or affirms rāhui in its original or historic sense: as a device to be employed by those (Maori) with mana whenua, with enforcement and penalties for breaching the rāhui unclear, but potentially very severe. On other occasions, the rāhui of legislation is a device available simply to those with statutory or governmental authority, and which is enforced as a statutory offence. On these occasions, we may observe 
important differences between rāhui as originally understood and rāhui as a legislative construct. Thus, Maxwell and Penetito comment on temporary closures under the Fisheries Act:

These temporary closures are also referred to as rāhui, possibly because they resemble voluntary rāhui. Temporary closures have been created from an anthropocentric worldview and not from a holistic worldview. Temporary closures are not designed to replenish mauri of the species in accordance with kaitiakitanga, but are designed to replenish the resource so the tangata whenua can continue to utilise the resource for the purpose of manaakitanga (providing food for their visitors). The current Minister of Fisheries is the only person who can install these temporary closures, based on anyone's recommendation, so long as the have the support of the majority of the community. Originally this was the right of only a person with mana ... So the role of the tohunga and chiefly members of a hapu (sub tribe) or iwi (tribe) effectively become the same as any other New Zealand citizen, as an advisor to the Minister of Fisheries and not an authority on the use of rāhui.

On a positive note, temporary closures are legally enforceable which brings the 'teeth' back into this type of rāhui. A Fisheries Officer can apprehend anyone caught violating the terms of a temporary closure and if found guilty they can be financially penalised ... Tangata whenua do not have the right to arrest or penalise an offender of a temporary closure or a voluntary rähui however they can [like any other person] assist the Fisheries Officer ... ${ }^{35}$

As we earlier observed, these differences between traditional conceptions and legislative constructions of rāhui may be rationalised or understood in more than one way. They may indicate on the part of legislators either a lack of understanding of rāhui or a simple unwillingness to create a legal form of rāhui that accurately replicates the traditional form (perhaps because this implies affirming the authority of Maori to make and enforce rāhui for the community as a whole). On the other hand, the differences may be seen to show how, ever flexibly, rāhui has adapted — or been adapted — to meet the needs and operate within the context of modern times. 
This text is taken from The Rahui: Legal pluralism in Polynesian traditional management of resources and territories, edited by Tamatoa Bambridge, published 2016 by ANU Press, The Australian National University, Canberra, Australia. 